\title{
Sensitivity of field isolates of Botryotinia ricini to fluazinam and thiophanate-methyl
}

\author{
Caroline de Oliveira Datovo $^{1} \cdot$ Dartanha J. Soares $^{2}$ (D)
}

Received: 16 April 2018 / Accepted: 4 July 2018 / Published online: 9 August 2018

(C) Sociedade Brasileira de Fitopatologia 2018

\begin{abstract}
This study aimed to determine the sensitivity of 61 Botryotinia ricini isolates to the fungicides fluazinam and thiophanate-methyl. The isolates were originated from Goiás $(n=3)$, Maranhão $(\mathrm{n}=3)$, Mato Grosso $(n=12)$, Minas Gerais $(\mathrm{n}=1)$, Paraíba $(n=8)$, Rio Grande do Sul $(n=19)$ and São Paulo $(n=15)$ states. Mycelial discs $(6 \mathrm{~mm})$ removed from 5-day-old colonies were transferred to Petri dishes containing potato dextrose agar (PDA) amended with different concentrations of the fungicides. Two perpendicular measurements of the radial growth were taken and used to calculate the percentage of mycelial growth inhibition (PMGI) for each treatment (isolate $\times$ fungicide $\times$ concentration) in relation to the control. PMGI were used to obtain the effective concentration that inhibits 50 and $95 \%$ of the mycelial growth $\left(\mathrm{EC}_{50}\right.$ and $\left.\mathrm{EC}_{95}\right)$ by means of linear regression. For fluazinam, the $\mathrm{EC}_{50}$ and $\mathrm{EC}_{95}$ (mean $\pm \mathrm{SD}$ ) were $0.1738 \pm 0.0802 \mu \mathrm{g} / \mathrm{mL}$ and $0.7938 \pm 0.1254 \mu \mathrm{g} / \mathrm{mL}$, while for thiophanatemethyl, the $\mathrm{EC}_{50}$ and $\mathrm{EC}_{95}$ were $0.3487 \pm 0.0963 \mu \mathrm{g} / \mathrm{mL}$ and $1.1325 \pm 0.2063 \mu \mathrm{g} / \mathrm{mL}$, respectively. Both fungicides have high intrinsic toxicity to $B$. ricini but fluazinam was a more potent growth inhibitor compared to thiophanate-methyl.
\end{abstract}

Keywords Castor gray mold $\cdot$ Chemical control $\cdot$ Fungicide sensitivity

Castor (Ricinus communis L.) is an oilseed crop usually cultivated in a low input agricultural system in the semiarid regions of Brazil. Castor oil is highly versatile and may be used in a wide range of industrial products, which has led to several initiatives aimed at promoting castor as a rotation crop in the Brazilian Cerrado (Severino et al. 2012). The castor gray mold, caused by Botryotinia ricini (Godfrey) Whetzel, is one of the most destructive diseases of castor. This pathogen has been described in almost all areas of castor cultivation, typically infecting the flowers and green capsules of the plants, and causing yield losses that may approach $100 \%$ (Soares 2012).

The best way to reduce the yield losses caused by this pathogen is through the use of genetic resistance. Unfortunately, none of the varieties available for cultivation

Section Editor: Sarah J. Pethybridge

Dartanha J. Soares

dartanha.soares@embrapa.br

1 Pontificia Universidade Católica-Campinas, Campinas, SP 13060-904, Brazil

2 Embrapa Algodão, Campina Grande, PB 58428-095, Brazil in the Brazilian Cerrado possess resistance to the gray mold pathogen, and those with some level of resistance do not have the agronomic traits required in this region and thus, fungicide applications are necessary to prevent yield losses (Severino et al. 2012; Soares 2012; Anjani et al. 2018). However, over time, the selection for fungicide-resistant individuals throughout the pathogen population may result in control failures (De Waard et al. 1993; Brent 1995). In fact, management of castor gray mold disease with fungicides has been challenging and the results have been inconsistent (Soares 2012). Studies to determine the intrinsic toxicity of the most promising molecules to be used in the management of this disease are lacking and may help to explain the inconsistency of the results.

The phylogenetic affinities and the similar biological behavior shared between Botrytis spp. and the causal agent of castor gray mold led us to hypothesize that fungicides regarded as highly effective against the genus Botrytis, the so called botryticides (Leroux 2007), will also be highly effective against $B$. ricini. Fluazinam and thiophanate-methyl are two molecules regarded as highly effective against Botrytis spp. (Leroux 2007; Hahn 2014; Shao et al. 2015). Therefore, the aim of the present work was to determine the intrinsic toxicity of these molecules to a collection of isolates of B. ricini obtained from distinct Brazilian regions. 
Table 1 Origin of the Botryotinia ricini isolates used in the present study

\begin{tabular}{llll}
\hline Region & State & Municipality & $\begin{array}{l}\text { Number of } \\
\text { isolates }\end{array}$ \\
\hline Central West & Goiás & Rio Verde & 3 \\
& Mato Grosso & Primavera do Leste & 12 \\
Northeast & Maranhão & Balsas & 3 \\
& Paraíba & Areia & 1 \\
& & Campina Grande & 4 \\
& & Esperança & 1 \\
Southeast & Minas Gerais & Remigio & 2 \\
& São Paulo & Viçosa & 1 \\
& & Jaguariúna & 3 \\
South & Rio Grande do Sul & Pindorama & 12 \\
Total & & Pelotas & 19 \\
\hline
\end{tabular}

Additionally, the use of fungicides to manage castor gray mold is likely to increase due to the expansion of castor crop in the Brazilian Cerrado. Thus, the results obtained in the present work are important for the establishment of a baseline sensitivity of this fungus to these fungicides to further aid in monitoring shifts towards fungicide resistance.

The bioassays were conducted during 2016 and 2017. The $B$. ricini isolates were obtained from diseased castor plants between 2012 and 2015. The isolates were preserved by freeze-drying in serum vials according to the ATCC protocol (ATCC 2011) and were deposited at the "Coleção de Culturas de Microrganismos Fitopatogênicos da Embrapa Algodão" (CCMF-CNPA). In total, sixty-one isolates, obtained in the states of Goiás $(n=3)$, Maranhão $(n=3)$, Mato Grosso $(n=$ 12), Minas Gerais $(\mathrm{n}=1)$, Paraíba $(n=8)$, Rio Grande do Sul $(n=19)$ and São Paulo $(n=15)$ were evaluated (Table 1$)$.

The sensitivity of the $B$. ricini isolates to the commercial fungicides Cercobin 500 SC (thiophanate-methyl 50\%, IHARABRAS S.A) and Frowncide 500 SC (fluazinam $39,84 \%$, IHARABRAS S.A) was determined by the mycelial growth inhibition assay. Mycelial discs (6 $\mathrm{mm}$ diameter), removed from the edges of 5-day-old colonies of all isolates, were transferred to Petri plates containing potato dextrose agar (PDA) amended with $0,0.09375,0.1875,0.375,0.75$ and $1.5 \mathrm{mg} \mathrm{ml}^{-1}$ of each active ingredient. The plates were then maintained in the dark at $25^{\circ} \mathrm{C}$ for 4 days. For each replicate, the diameter of the colony was obtained by measuring the fungus growth in two perpendicular directions from which the original mycelial disc was subtracted. These measurements were used to obtain the percentage of mycelial growth inhibitions in relation to the non-amended (control) plates. The effective concentration that inhibits 50 and $95 \%$ of the fungus growth $\left(\mathrm{EC}_{50}\right.$ and $\left.\mathrm{EC}_{95}\right)$ for each active ingredient was obtained by means of linear regression of the relative percentage of mycelial growth inhibition against the $\log _{10}$-transformed fungicide concentration (Hilber and Schuepp 1996; Liang et al. 2015; Liu et al. 2018), using SAS® and R (R Core Team 2016) statistical packages. For each combination (concentration $\times$ fungicide $\times$ isolate), three replicates were used and the bioassay was performed twice. Graphs were built using the ggplot2 package for R (Wickham 2009).

The $B$. ricini isolates were highly sensitive to fluazinam and thiophanate-methyl: $\mathrm{EC}_{50}$ and $\mathrm{EC}_{95}$ were $<50 \mu \mathrm{g} \mathrm{ml}^{-1}$ (Grindle 1981) (Table 2). Isolates collected from the four distinct geographical regions, viz. South, Southeast, Central West and Northeast, showed similar sensitivity levels to the fungicides evaluated. The $\mathrm{EC}_{50}$ values of $0.1738 \pm 0.0802 \mu \mathrm{g} \mathrm{mL}^{-1}$ and $0.3487 \pm 0.0963 \mu \mathrm{g} \mathrm{mL}^{-1}$ can be used as the baseline to monitor the sensitivity of $B$. ricini to fluazinam and thiophanate-methyl, respectively.

The isolates had a narrow unimodal distribution regarding their sensitivity to both active ingredients (Fig. 1). Based on the mean $\mathrm{EC}_{50}$ and $\mathrm{EC}_{95}$ values, in general, fluazinam was twice as toxic to $B$. ricini as thiophanate-methyl. For the $\mathrm{EC}_{50}$ values, a weak, but significant, association of isolate sensitivity to both fungicides (Spearman rank correlation coefficient $=$ $0.271, P=0.03$ ) was observed, while for $\mathrm{EC}_{95}$, no significant association was observed. This suggests that most sensitive isolate to thiophanate-methyl was not necessarily the most sensitivity isolate to fluazinam, and vice-versa. This lack of correlation was expected as the fungicides evaluated here have biochemically distinct modes of action (Leroux 2007).

Chagas et al. (2014) claimed that B. ricini was highly sensitive to several fungicides, including thiophanate-methyl, since the $\mathrm{EC}_{50}$ observed was lower than $1 \mu \mathrm{g} \mathrm{mL}^{-1}$. However, since a single isolate of the fungus had been used, their results cannot be considered conclusive, especially due to the large variations usually observed among distinct isolates (Grindle 1981). In this study, we evaluated 61 field isolates of
Table 2 Variations between fluazinam and thiophanatemethyl concentrations ( $\mu \mathrm{g}$ a.i. $\mathrm{ml}^{-1}$ ) which inhibited mycelial growth of 61 field isolates of Botryotinia ricini from Brazil

\begin{tabular}{lllll}
\hline Antifungal compound & Growth inhibition $(\%)$ & Range & Average (mean \pm SD) & Median \\
\hline Fluazinam & 50 & $<0.0937$ to 0.4232 & $0.1738 \pm 0.0802$ & 0.1621 \\
& 95 & 0.6373 to 1.2456 & $0.7938 \pm 0.1254$ & 0.7646 \\
Thiophanate-methyl & 50 & 0.1039 to 0.4772 & $0.3487 \pm 0.0963$ & 0.3507 \\
& 95 & 0.7637 to $>1.5$ & $1.1325 \pm 0.2063$ & 1.1746 \\
\hline
\end{tabular}



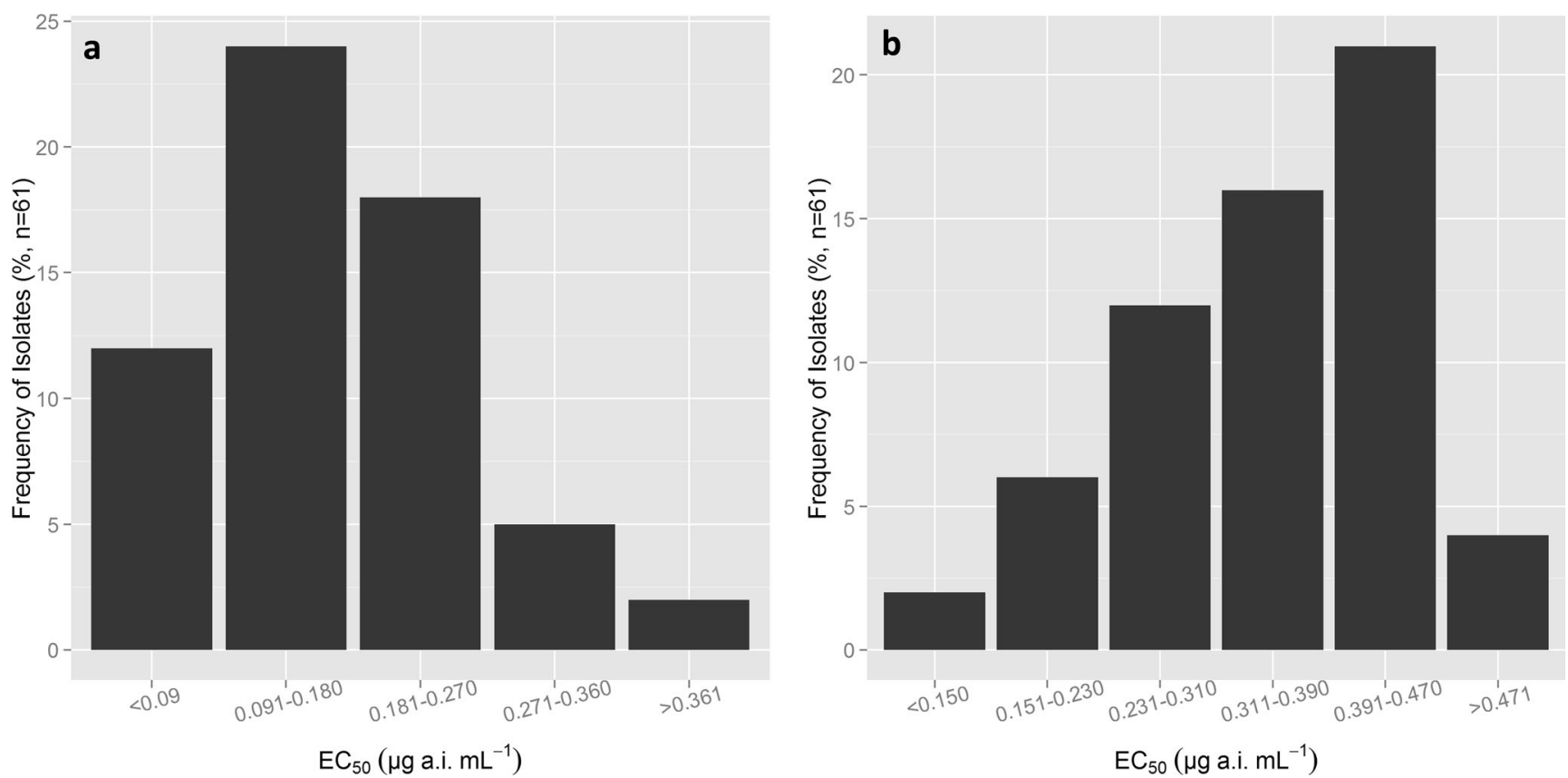

Fig. 1 Frequency distribution of $\mathrm{EC}_{50}$ values for fluazinam (a) and thiophanate-methyl (b) based on mycelial growth of 61 field isolates of Botryotinia ricini from Brazil

B. ricini, obtained from 11 municipalities covering four Brazilian regions. Our results show that thiophanate-methyl and fluazinam have high intrinsic toxicity to the fungus, which corroborates the claim of Chagas et al. (2014) and establishes the baseline sensitivity of $B$. ricini to thiophanate-methyl and fluazinam.

The $\mathrm{EC}_{50}$ values for all isolates evaluated were lower than $0.5 \mu \mathrm{g} \mathrm{ml}^{-1}$ showing absence of resistant phenotypes, for both a.i., amongst the Brazilian isolates of B. ricini (Table 2). However, three isolates obtained from Rio Verde, Goiás, had been exposed to conventional fungicides during the 2015 crop season. According to the grower, one prophylactic iprodione and two curative azoxystrobin spraying were made before isolates had been collected. These active ingredients belong to distinct biochemical groups from those used in the present work. Additionally, by performing a hierarchical clustering analysis using the FactoMineR package for $\mathrm{R}$ (Le et al. 2008), this fungicide exposure had no effect on clusters, which were determined exclusively by $\mathrm{EC}_{50}$ values. Thus, we suggest that despite this fungicide exposure, the $\mathrm{EC}_{50}$ values obtained in the present work may serve as baseline sensitivity of $B$. ricini to these fungicides.

The absence of resistant phenotypes was already expected as no constant selection pressure was applied over the fungus population where the isolates had been collected. However, selection for resistant phenotypes is commonly observed in Botrytis spp. population exposed to frequent fungicide application (Northover and Matteoni 1986; Leroux 2007; Liu et al. 2018). Thus, since B. ricini is phylogenetically and biologically similar to Botrytis spp., the selection for fungicide resistant individuals within B. ricini population may also be a concern, especially when applying fungicides with a highrisk of resistance (Leroux 2007). Understanding the genetic basis of fungicide resistance plays an important rule to formulate strategies to overcome it. The benefits of this understanding are well documented, especially for Botrytis spp. (De Waard et al. 1993). Nonetheless, no studies to determine the genetic basis for fungicide resistance are available for B. ricini and this situation is likely to endure. Thus, the data presented here are important since they provide insights into the sensitivity of B. ricini to two fungicides that may be used for managing this disease.

Acknowledgements The first author thanks CNPq for her fellowship grant. The senior author would like to thanks the CNPq (Proc. 472953/ 2009-5) and Petrobras (TC 0050.0064181.10.9) by research grants on castor diseases.

\section{References}

Anjani K, Raof MA, Prasad MSL, Duraimurugan P, Lucose C, Yadav P, Prasad RD, Jawahar Lal J, Sarada C (2018) Trait-specific accessions in global castor (Ricinus communis L.) germplasm core set for utilization in castor improvement. Industrial Crops and Products 112: 766-774

ATCC (2011) Preservation and recovery of filamentous fungi. Technical Bulletin $\mathrm{N}^{\circ} 2.4$ p. Available at: https://www.atcc.org/ /media/PDFs/ Technical\%20Bulletins/tb02.ashx

Brent KJ (1995) Fungicide resistance in crop pathogens: how can it be managed? Global Crop Protection Federation. FRAC, Monograph $\mathrm{N}^{\circ} 1$. Brussels

Chagas HA, Basseto MA, Rosa DD, Toppa EVB, Furtado EL, Zanotto MD (2014) Avaliação de fungicidas, óleos essenciais e agentes 
biológicos no controle de Amphobotrys ricini em mamoneira (Ricinus communis L.). Summa Phytopathologica 40:42-48

De Waard MA, Georgopoulos SG, Hollomon DW, Ishii H, Leroux P, Ragsdale NN, Schwinn FJ (1993) Chemical control of plant diseases: problems and prospects. Annual Review of Phytopathology 31:403-421

Grindle M (1981) Variations among field isolates of Botrytis cinerea in their sensitivity to antifungal compounds. Pesticide Science 12:305-312

Hahn M (2014) The rising threat of fungicide resistance in plant pathogenic fungi: Botrytis as a case study. Journal of Chemical Biology 7: 133-141

Hilber UW, Schuepp H (1996) A reliable method for testing the sensitivity of Botryotinia fuckeliana to anilinopyrimidines in vitro. Pesticide Science 47:241-247

Le S, Josse J, Husson F (2008) FactoMineR: an R package for multivariate analysis. Journal of Statistical Software 25:1-18

Leroux P (2007) Chemical control of Botrytis and its resistance to chemical fungicides. In: Elad Y, Williamson B, Tudzynski P, Delen N (eds) Botrytis: biology, pathology and control. Springer, Dordrecht, pp 195-222

Liang HJ, Li JL, Di YL, Zhang AS, Zhu FX (2015) Logarithmic transformation is essential for statistical analysis of fungicide EC50 values. Journal of Phytopathology 163:456-464

Liu S, Fu L, Hai F, Jiang J, Che Z, Tian Y, Chen G (2018) Sensitivity to boscalid in field isolates of Sclerotinia sclerotiorum from rapeseed in Henan Province, China. Journal of Phytopathology 166:227-232

Northover J, Matteoni JA (1986) Resistance of Botrytis cinerea to benomyl and iprodione in vineyards and greenhouses after exposure to the fungicides alone or mixed with Captan. Plant Disease 70:398-402

R Core Team (2016). R: a language and environment for statistical computing. $\mathrm{R}$ foundation for statistical computing, Vienna, Austria. URL http://www.R-project.org/

Severino LS, Auld DL, Baldanzi M, Cândido MJD, Chen G, Crosby W, He X, Lakshmamma P, Lavanya C, Machado OTL, Milani M, Mielke T, Miller TD, Morris JB, Navas AA, Soares DJ, Sofiatti V, Tan D, Wang ML, Zanotto MD, Zieler H (2012) A review on the challenges for increased production of castor. Agronomy Journal 104:853-880

Shao W, Ren W, Zhang Y, Hou Y, Duan Y, Wang JX, Zhou M, Chen C (2015) Baseline sensitivity of natural population and characterization of resistant strains of Botrytis cinerea to fluazinam. Australasian Plant Pathology 44:375-383

Soares DJ (2012) Gray mold of castor: a review. In: Cumagun CJR (ed) Plant pathology. InTech Publishing, Rijeka, pp 219-240

Wickham H (2009) ggplot2: elegant graphics for data analysis. Springer, New York 